\title{
DATING HISTORICAL CONTEXTS: ISSUES, PLANT MATERIAL, AND METHODS TO DATE THE LATE ROMAN SITE OF FARAGOLA, APULIA (SE ITALY)
}

\author{
V Caracuta $^{1,2} \bullet \mathrm{G} \mathrm{Fiorentino}^{1} \bullet \mathrm{M} \mathrm{Turchiano}^{3} \bullet \mathrm{G}$ Volpe $^{3}$
}

\begin{abstract}
Charred plant materials found in archaeological contexts are usually considered the most reliable remains for radiocarbon dating. Usually, seeds and fruits are preferred to wood fragments because their short lifecycle reduces the range of uncertainty of the ${ }^{14} \mathrm{C}$ measurement. A selection of short-lived samples, mainly from barley and wheat, from the Late Roman site of Faragola (SE Italy) were ${ }^{14} \mathrm{C}$ dated; however, the ${ }^{14} \mathrm{C}$ dates obtained were not always consistent with the chronology provided by other archaeological evidence. A careful analysis of all the macrobotanical remains found in each of the dated contexts provides insight into the origin of the plant material, helping to distinguish between in situ and non-in situ material. The ${ }^{14} \mathrm{C}$ dates are reconsidered in the context of findings and the kind of material selected for dating. Using the archaeological context, a Bayesian model was employed to reduce the range of the calibrated date and thereby refine the chronology of the site on an absolute basis.
\end{abstract}

\section{INTRODUCTION}

This study investigates the potential of archaeobotanical analysis as a means to obtain accurate radiocarbon dating in the multistratified site of Faragola, a settlement developed at the beginning of the 1st millennium AD in southeastern Italy. Despite the long-term occupation of the site, the main evidence is datable to the Late Roman period when a villa farm was built and then abandoned as a consequence of the collapse of the Roman economic system. The reoccupation of the site in the early Middle Ages offers an unprecedented opportunity to determine the chronology of the transition from a Roman villa system to a village-based system that spread at the beginning of the Middle Ages. Archaeologists and historians have long debated the time of this transition. Several hypotheses have been tested, but the results continue to be debated since the transition appears to have taken place in different areas of the former Roman Empire at different times (Francovich and Hodges 2003; Lewit 2003).

The site of Faragola represents the first attempt to date this transition in the Apulia region with an absolute chronology, but ${ }^{14} \mathrm{C}$ samples need to be carefully selected because of the extended occupancy of the site during two distinct eras. Sites with long-term occupation are challenging to accurately date using ${ }^{14} \mathrm{C}$ analysis for several reasons. In the site of Faragola, one of the main challenges arises from the presence of several strata, one on top of the other, corresponding to different periods of occupation that are close in time ( 100-200 yr); in such a condition, the possibility of dating intrusive samples is very high, since vegetal material might have entered the deposit only later, as a result of natural and anthropic postdepositional events, such as furrows, holes, gravesites dug in layers of the previous phases, reoccupation of households, or reuse of ancient carpentry.

Understanding the archaeological context and the origin of the archaeobotanical assemblage is required to select the most representative specimen for ${ }^{14} \mathrm{C}$ dating. Nonetheless, the extensive calibration range of the ${ }^{14} \mathrm{C}$ dating technique can introduce significant uncertainties to the measured dates. In order to refine the ${ }^{14} \mathrm{C}$ chronology for the site at Faragola, we coupled the study of the archaeological context and the identification of the archaeobotanical assemblage to exclude intrusive elements. Fifteen of the 16 dates presented here were already published, but their value as chronological indi-

1. Laboratory of Archaeobotany and Paleoecology (L.A.P.), Università del Salento, via D. Birago 64, 73100 Lecce, Italy.

2. D-Reams Radiocarbon Laboratory, Weizmann Institute of Science, Herzl Street 274, 76100 Rehovot, Israel.

Corresponding author. Email: valentina.caracuta@weizmann.ac.il.

3. Department of Human Science (DISCUM), Università di Foggia, via Arpi 176, 71121 Foggia, Italy.

Proceedings of the Radiocarbon and Archaeology 7th International Symposium

Ghent, Belgium, April 2013 | Edited by Mark Van Strydonck, Philippe Crombé, and Guy De Mulder

(C) 2014 by the Arizona Board of Regents on behalf of the University of Arizona 
cators has never been exploited (Fiorentino et al. 2009; Caracuta and Fiorentino 2012). This article uses these dates to construct a Bayesian model in order to reduce the range of the calibrated date. As a result, the modeled dates refine the chronology of the site on an absolute basis.

\section{THE SITE}

The excavation of a large area within the territory of the Ascoli Satriano (ancient Ausculum) in southern Italy has brought to light an articulated rural complex that developed for a thousand years. The archaeological remains found in this area, called Faragola, include an Iron Age (Daunian) tribal settlement, a villa farm of the Early Roman period, a large Late Roman villa, and an Early Medieval village. However, the Late Roman residence is by far the most important site in the area (Volpe and Turchiano 2009, 2010, 2012).

The excavation of the phases belonging to the Late Roman period led to the discovery of an elaborate thermal complex, a monumental dining room, and different service rooms and warehouses (Volpe and Turchiano 2012). After the abandonment of the Faragola villa, the complex was partly incorporated into early Medieval settlements, where the remains of a few huts, tombs, and a metal workshop have been discovered (Volpe et al. 2009, 2012) (Figure 1a,b).

A

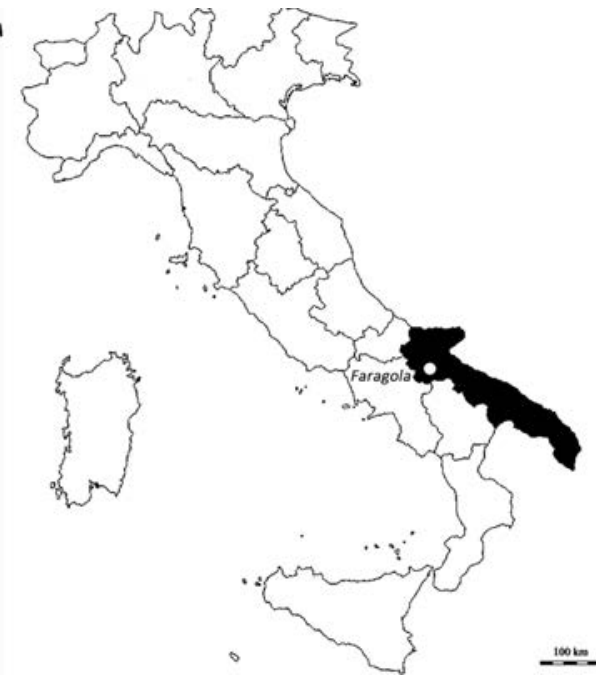

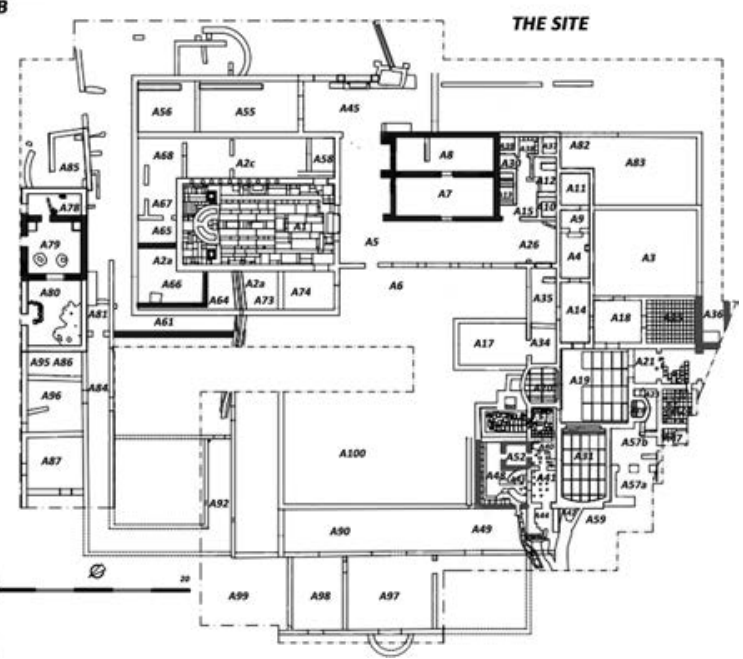

Figure 1 (A) The location of the site within the Italian Peninsula; (B) schematic drawing of the site. The numbers (An) within the squares refer to the locus number. The investigated contexts are marked in bold; gray contours indicate the Late Roman (LR) rooms while the black the Early Middle Age (EMA). Granaries A7 and A8 are marked in black because the material contained in these granaries dated to the EMA, although they were constructed during the LR.

\section{Contexts Investigated and the Archaeological Chronology}

Part of the material selected for dating the Late Roman (LR) phase was collected from three furnaces (A36, A52, and A48) used to heat the bathhouse of the villa. A well-preserved mosaic on the floor of a large salon near furnace A36 includes iconographic motifs that might date the construction of the eastern part of the complex to the 2nd-3rd century AD. Other archaeological evidence in the western side, namely the technique of construction of the walls, suggested that this building was built later, likely in the 4th century AD. A study of the stratigraphy of the walls of the two furnaces in this area (A52 and A48) indicates two distinct periods of construction: one dating to the 4th century and the other one between the 5th and 6th century AD. 
The pottery-kiln built in the courtyard of the villa can be ascribed to the LR period (end of the 4th to beginning of the 5th century). Unfortunately, the species of the selected wood sample is unknown since it was dated before the archaeobotanical investigations started in the site. The last samples for this period were selected among the material found in the storeroom A7 of the villa. This granary was built together with another symmetric warehouse A8 using a technique that dates the structures to the 4th century AD when the first LR villa was built. The granaries contain metal tools such as sickles, picks, and a hatchet, as well as pottery, in a style dating from the 7th century AD; therefore, the granaries were used and occupied for several centuries (Arthur and Patterson 1994, 1998; La Salvia 2007; Goffredo and Maruotti 2012; Scrima and Turchiano 2012).

As part of the study of the early Middle Ages (EMA) occupation of the site, two refuse dumps and a domestic hearth were sampled. The dumps were dug in two preexisting rooms (A66 and A61) that belonged to the early Roman villa farm. The dumps were filled with materials recycled from disused buildings within the site including pottery, glass, marbles, metal objects, and refuse of metal working datable between the 2 nd century $\mathrm{BC}$ and the end of the 6th century $\mathrm{AD}$. The latest context sampled was a hearth (US 7056) found in hut A79 that belongs to the complex of ephemeral structures built in the 6th century AD (Figure 1b).

\section{MATERIAL AND METHODS}

Extensive site excavation was coupled with microstratigraphical excavation of specific contexts in order to understand the processes that led to the accumulation of archaeological layers in various contexts, including furnaces, storerooms, and dumps, where a prolonged use is conceivable.

\section{Archaeobotany}

Once the context was assessed and possible causes of contamination between layers were excluded, samples of sediments were collected and wet-sieved (mesh width 1-2 mm). Charcoals were separated from other remains (mainly microfauna, pottery, and metal slags) and the anatomical features of charred wood tissue and seeds were analyzed by stereoscopic (Nikon SMZ 645) and metallographic (Nikon Eclipse ME600) microscopy.

Comparison with local plant reference material available at the Laboratory of Archaeobotany and Palaeoecology of the University of Salento led to the taxonomical identification of 3738 charcoals and $2233 \mathrm{seed} /$ fruits (Caracuta and Fiorentino 2009). Deciduous oak (Quercus cf. pubescens), mastic tree (Pistacia cf. lentiscus), buckthorn (Rhamnus/Phillyrea), and service tree (Sorbus cf. domestica) were the major components of the fuel used in the furnaces (A36, A48, and A52) and the hearth (A79). The first two species were found in abundance among the fragments of charred wood in the dump A61.

Ash (Fraxinus cf. excelsior), juniper (Juniperus sp.), poplar/willow (Populus/Salix), and elm (Ulmus cf. minor) were the most common elements of the carpentry and furniture used in the storerooms (A7 and A8). A mix of all these species, also including olive (Olea europaea), evergreen oak (Quercus cf. ilex), plum (Prunus sp.), maple (Acer sp.), and pomegranate (Punica granatum), was found mixed with miscellaneous refuse in the dump A66 (Figure 2; Table 1).

Among the nine contexts investigated, only five had seeds. Wheat (Triticum aestivum/compactum) was mainly found in the storeroom A8, while a good deal of barley (Hordeum vulgare, $H$. distichum) was found in the storeroom A7, together with bitter vetch (Vicia ervilia) and pea (Pisum sativum). Remains of peas were discovered in the hearth of hut A79 where other legumes were found: chickpea (Cicer arietinum), lentils (Lens culinaris), vetch (Vicia sp.), and sweet peas (Lathyrus sp.). 


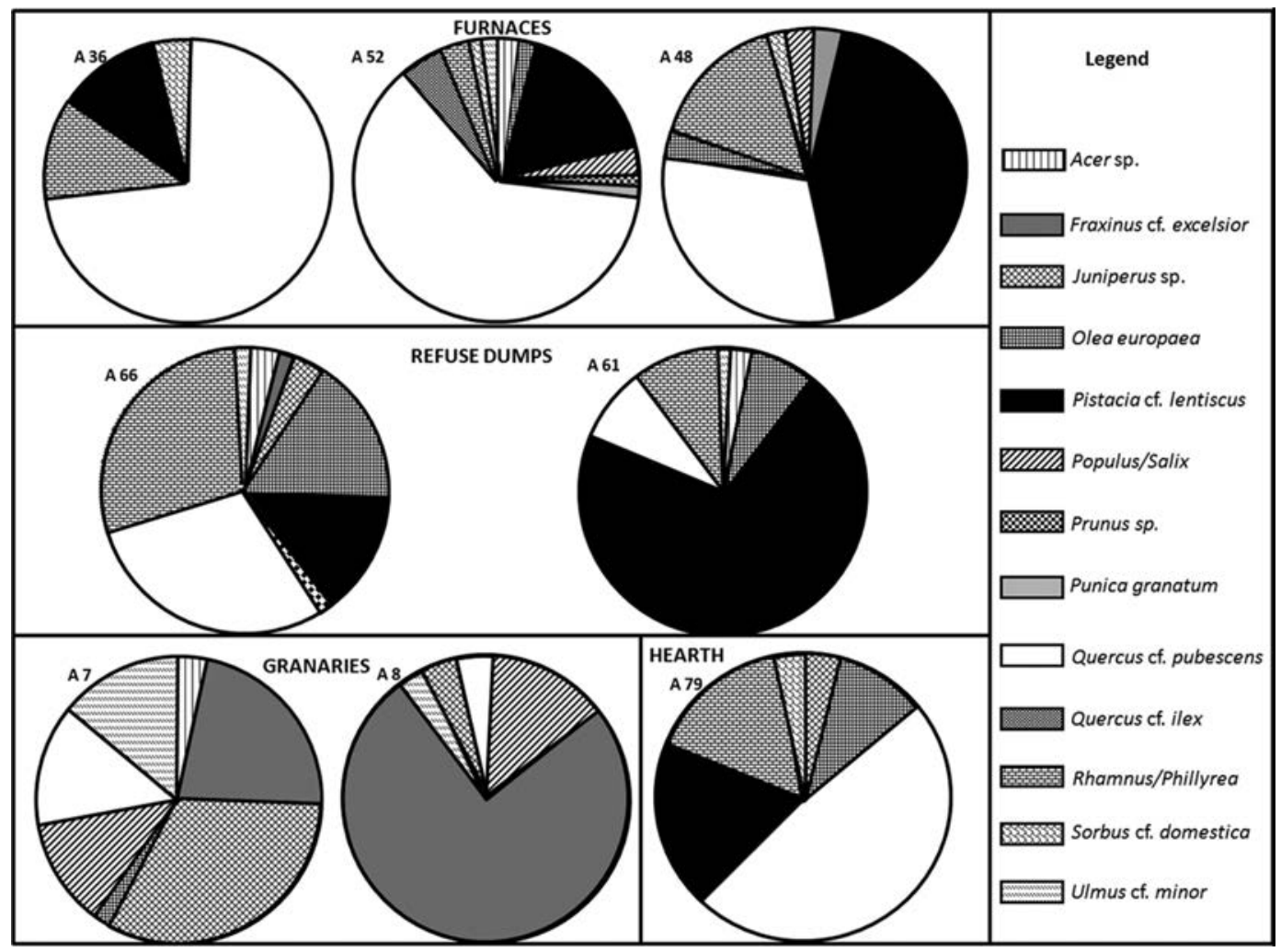

Figure 2 Percentage of wood charcoals divided by contexts

Olive pits (Olea europaea) were recovered in the hearth A79, but also in the refuse heap A66, where they were found together with cereal, legumes, and grape seeds (Vitis vinifera). Grape was the major component of the few seeds discarded in the dump A61 (Figure 3; Table 2).

\section{Which Plant Material for Which Contexts?}

Once the archaeobotanical assemblage was identified, material for ${ }^{14} \mathrm{C}$ dating was selected in a way that reduced the possibility of taking intrusive elements. Species of wood or seeds that were predominant were preferred for dating because they were considered less likely to be intrusive. Branches of wood were selected among those that still had bark preserved and had $<20$ rings. The outermost ring was chosen for dating in order to minimize the old-wood effect.

Twigs (5-10 rings) of charred wood were taken from the bathhouse furnaces (A36, A48, and A52), and the fireplace found in the early Medieval hut (A79). Wood was considered to be more reliable for ${ }^{14} \mathrm{C}$ dating than seeds since it is used as a fuel for fire, whereas seeds were likelier to be intrusive.

Particular care was taken when sampling the furnace A52. Half of the ashy deposit that filled the furnace was removed and a section exposed. The study of this section revealed that layers of ash and charcoals were repeatedly covered with plaster to ensure the function of the furnace itself. Therefore, the samples selected for ${ }^{14} \mathrm{C}$ dating were taken from the bottom part and the upper part of the section in order to get the widest range of use of the structure (Figure 4). Deciduos oak (Quercus cf. pubescens) and mastic tree (Pistacia cf. lentiscus) were selected since they were most commonly used for fueling (Caracuta and Fiorentino 2012). 

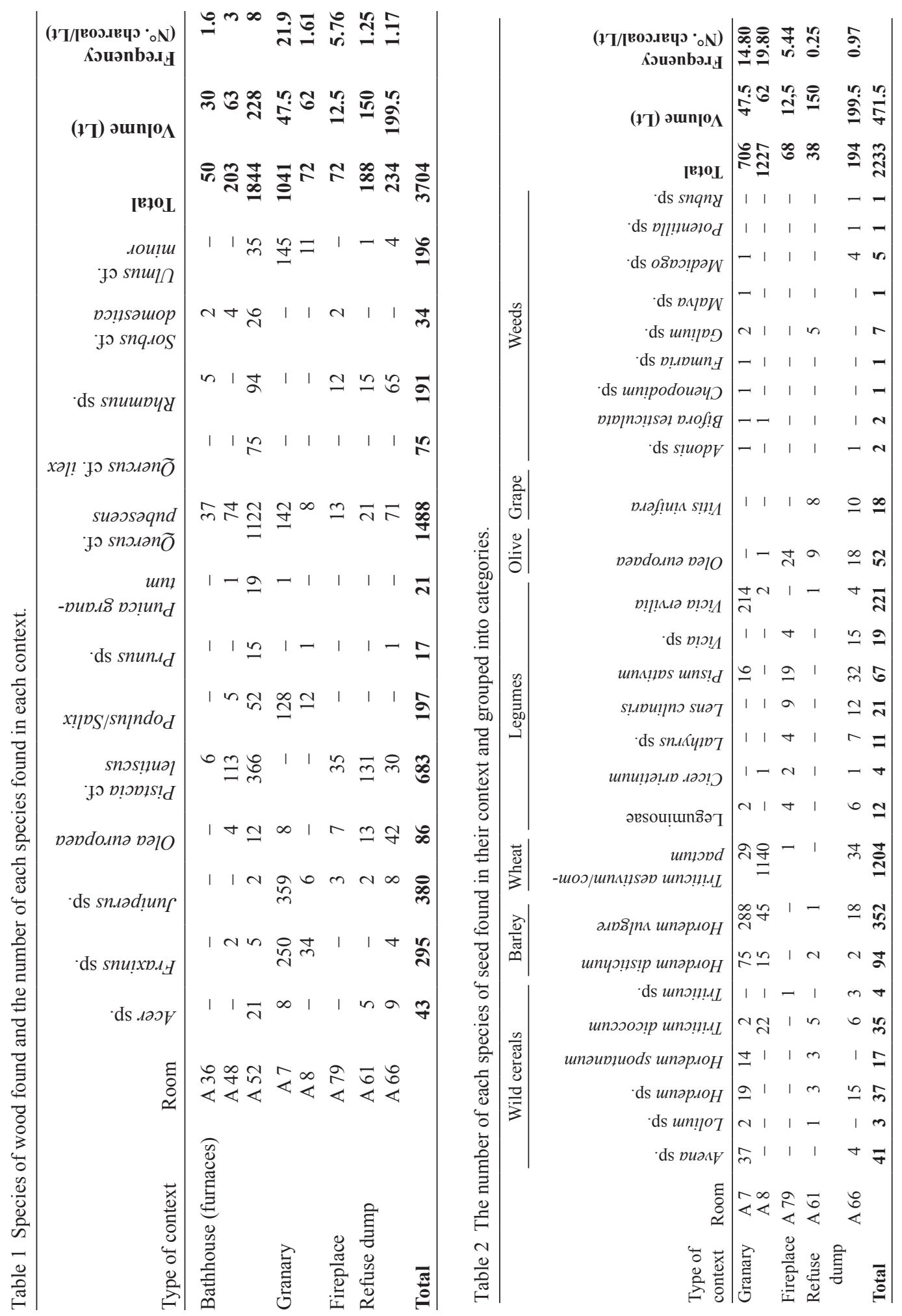


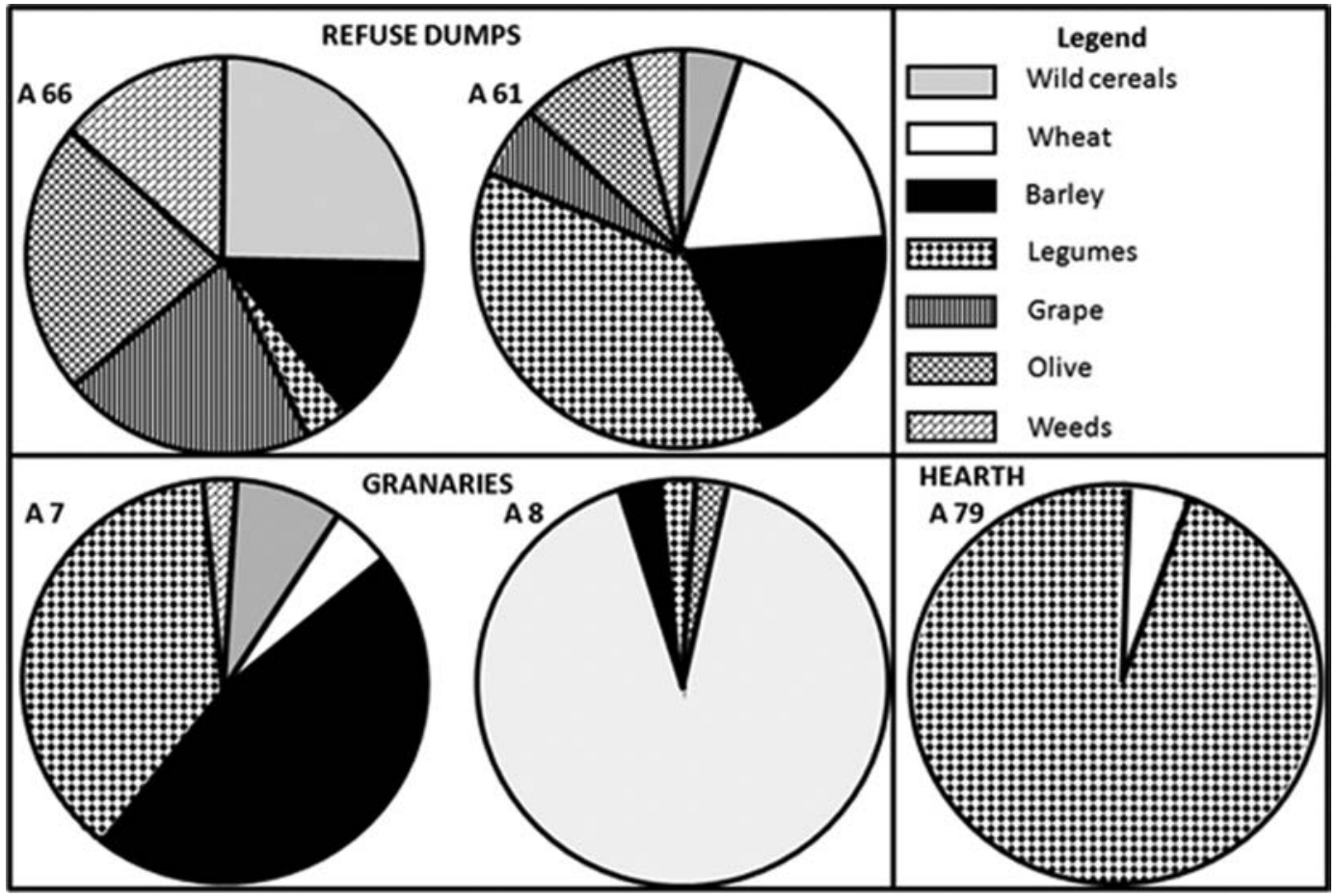

Figure 3 Percentage of seeds' categories divided by contexts of finding. For details about the single species included in each category, see Table 2 . Note that not all the contexts had seeds remains.

A sample of wood was also chosen among the charcoals found in the granary A8, mainly to compare the resulting ${ }^{14} \mathrm{C}$ date to that of the cereals stored in the storeroom. In this case, a small branch (5-7 rings) of juniper (Juniper sp.) was preferred instead of the oak, since this species was much more ubiquitous.

The majority of specimens chosen for dating the granaries were cereal grains. The samples were not chosen randomly: wheat (Triticum aestivum/compactum) was selected for dating the granary A8 since it was the dominant species, just as the barley (Hordeum vulgare) was the dominant species found in granary A7.

A test sounding had been previously carried out the storeroom A7 and a section of the archaeological deposit exposed. Studying the strata visible on the section, a remarkable distinction was found between the bottom, sealed by a thick layer of the remains of the collapsed roof, and the upper part. Four grains of barley were collected for dating, two of them from the layers that stand above the remains of the collapsed roof and two from below it. The samples from the dumps A61 and A66 were more challenging because the two rooms had been filled with debris coming from all around the site including pottery, marble, glass, and metal objects dating from the 2nd to 6th century AD.

The material coming the different rooms was quantified in order to check if there was any difference in the composition of the debris that might suggest a different origin of the discarded material. Remains of metalworking were found predominantly in A61, while marble, pottery, and glass were mainly found in A66 (Caracuta et al. 2012). 


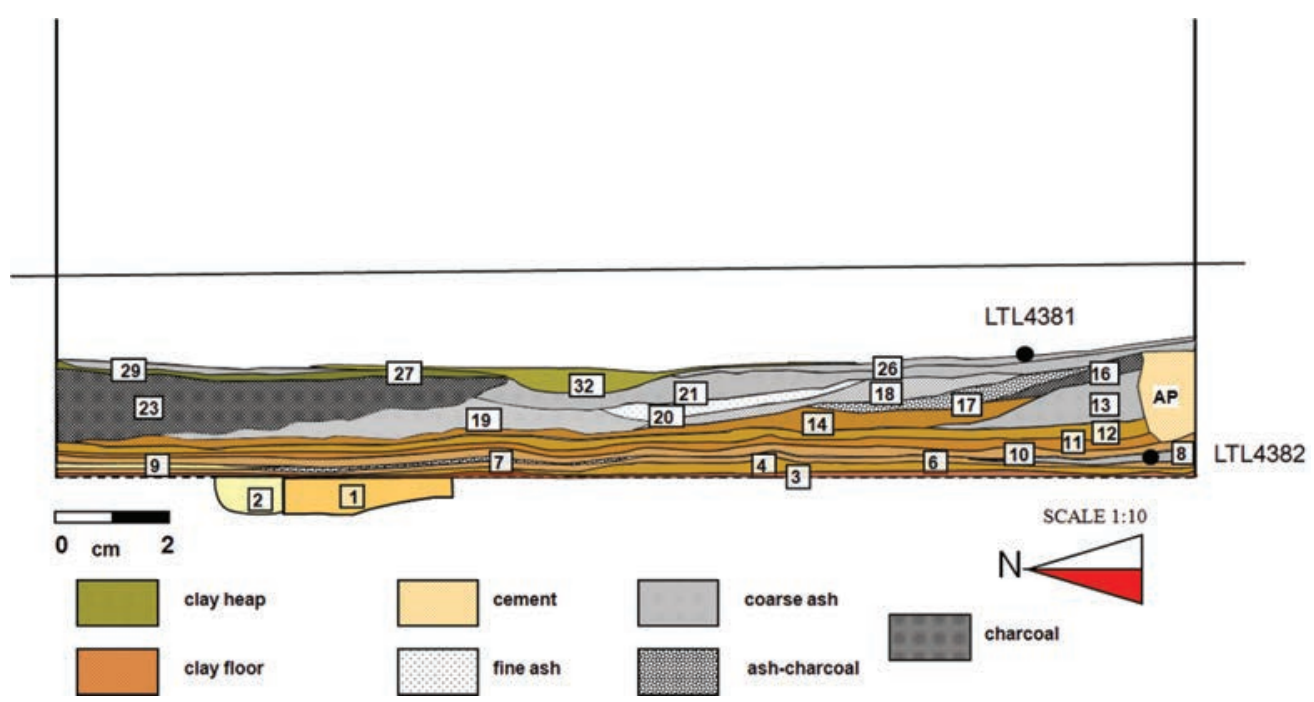

Figure 4 Schematic drawing of the section of furnace A52. Black spots indicate the position of the ${ }^{14} \mathrm{C}$ dates. Numbers refer to the locus number.

The archaeobotanical assemblage reflected this difference: large chunks of charcoal and branches were largely recorded in A61, while cereals and legumes were mostly found in room A66. Comparing the archaeological evidence to the archaeobotanical data, it resulted that the deposit of A66 was made by material coming from dismissed rooms of the villa, while A61 had likely been filled with refuse from metalworking activities contemporaneous to the establishment of the EMA settlement.

The difference of these two deposits was taken into account when choosing material for ${ }^{14} \mathrm{C}$ dating. A grain of wheat was preferred in A66 because of the "domestic" origin of the material dump in this room, while the deposit of room A61 was dated using a branch of deciduous oak (5 rings). To prove the reliability of this hypothesis, a grain of wheat coming from A61 was also dated. It was an outlier compared to the rest of the assemblage, and had a different ${ }^{14} \mathrm{C}$ date than the oak, consistent with our hypothesis that the context must be considered when choosing samples for ${ }^{14} \mathrm{C}$ dating.

\section{Radiocarbon and Statistical Analyses}

All the specimens were analyzed by accelerator mass spectrometry (AMS) at the CEDAD Laboratory, University of the Salento, in accordance with standard procedures (for details see D'Elia et al. 2004; Calcagnile et al. 2005; Quarta et al. 2005). Conventional ${ }^{14} \mathrm{C}$ ages obtained at CEDAD (lab code LTL) were calibrated against IntCal09 (Reimer et al. 2009) and converted to calendar ages using OxCal v 4.2.2 (Bronk Ramsey 2013). The dates already published were recalibrated using this newest version of OxCal.

Several dates showed a large range of calibration; therefore, other dating evidence such as pottery, building technique, stratigraphy, etc. were taken into account to reduce the timespan of specific archaeological contexts. OxCal v 4.2.2 was used to build a Bayesian model that put in sequence the Late Roman (LR) and the early Middle Ages (EMA) sequences. These sequences were built using stratigraphical observation and stylistic evidence from the finds, and then constrained by the TPQ (terminus post quem) and TAQ (terminus ante quem). The TAQ for the LR sequence was fixed to the 2nd century AD based on the mosaic found in the eastern part of the bathhouse near A36. The end of the LR sequence (TPQ) was set at the end of the 5 th century AD, based on the pottery shards 


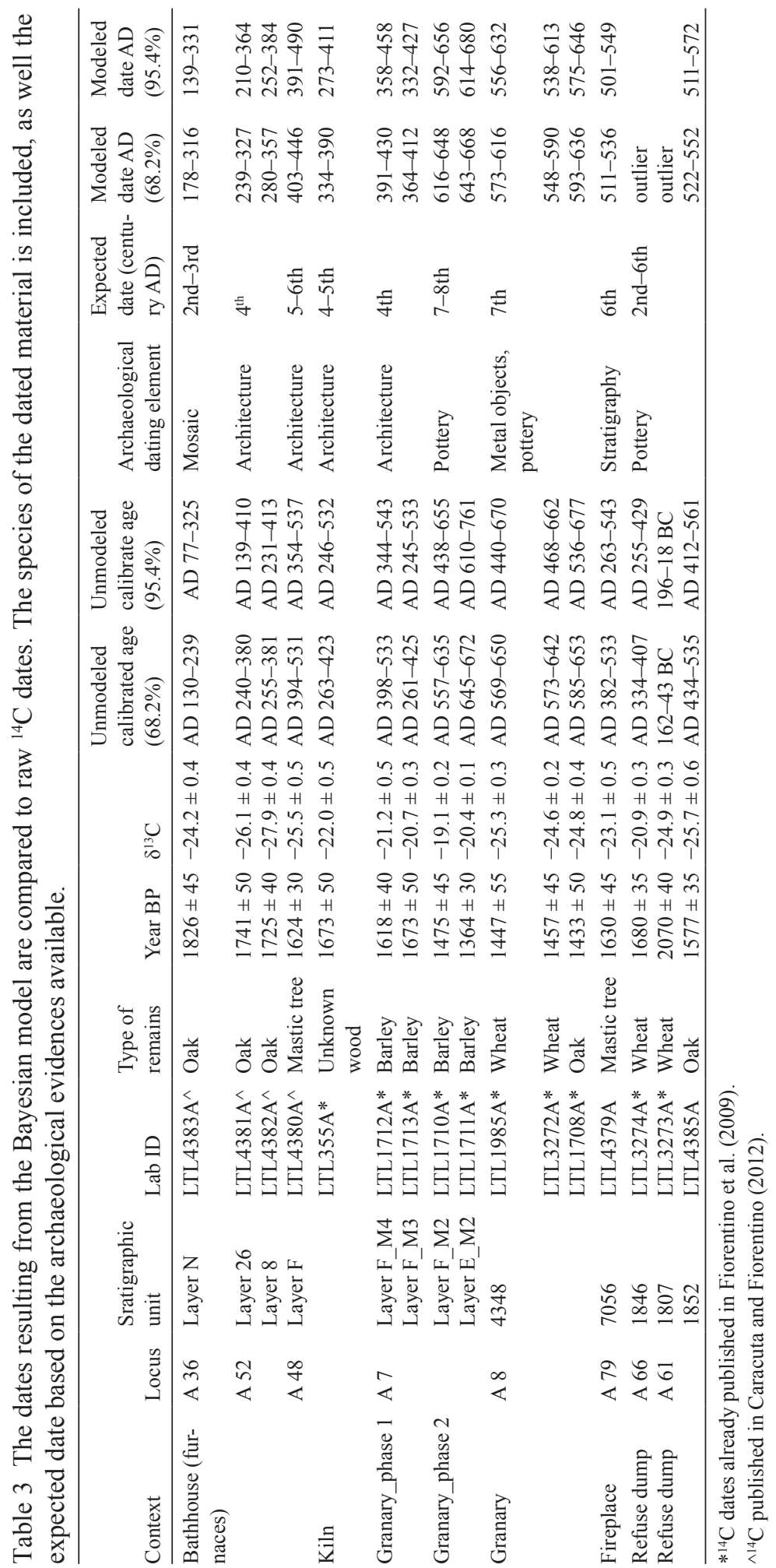


found in the Late Roman villa. The LR sequence included the dates coming from the furnaces of the bathhouse, the pottery kiln, and the first phase of the granary A7 (A7_1).

The date coming from the oldest part of the bathhouse (LTL4380A) is the first in the sequence, followed by the sequences of dates coming from the furnace A52. After those come the date of the pottery kiln (LTL355A) and the sequence of dates of the first phase of the granary A7_1. The date coming from the furnace A48 (LTL4380) closes the LR sequence since this part of the bathhouse was added only at the very end of the life of the villa.

For the EMA sequence, the TAQ was fixed at the beginning of the 6th century $\mathrm{AD}$, when the villa was in ruin and the village was first established, while the TPQ was set at the beginning of the 8th century $\mathrm{AD}$, when the village fell into disuse. The EMA sequence includes the dates from the hearth (US 7069) of the hut (A79), the dump A61, the granary A8, and the layer above the roof of the granary A7, corresponding to its reuse (A7 2). The first date from the hearth (LTL4379A) of the hut belongs to the oldest nucleus of the EMA settlement, and therefore opens the sequence. The date from A_61 (LTL4385A) comes soon after the date of the hut, since the dump was created after the settlement of the site. The dates coming from the granaries A8 and A7_2 were plotted in two sequences with the sequence of the granary A8 preceding the sequence of the granary A7_2 on the basis of the pottery and metal objects found inside the two storerooms.

\section{RESULTS \\ AMS Dating}

The 16 dating results cover a time period of 8 centuries, from the 1 st century $\mathrm{BC}$ to the $7-8$ th centuries AD. Despite the selection of the plant material aimed at choosing the most reliable samples, most of the dates have a large range of calibration ( $200 \mathrm{yr})$. This is especially true for LTL 1985A, 3272A, 4379A, 1712A, 1713A, 4381A, and 4383A.

The grain of wheat from the refuse heap A61 (LTL3274A) turned out to be very old (2nd century $\mathrm{BC})$. This sample, already an outlier compared to the archaeobotanical assemblage, was considered intrusive. Indeed, the other specimen from the same context, a branch of oak (LTL4385A) dates to the 6th century $\mathrm{AD}$ in accordance with archaeological chronology of the dump. In agreement with the assumption that the refuse heaps (A61 and A66) were both created at the beginning of the EMA, the date LTL3274A, coming from A66, was also excluded from the model since it was dated to the LR period. Fourteen of the 16 samples were used in the model. This shows a good degree of agreement (A: 121) and leads to a refined chronology of the site and the different phases.

\section{DISCUSSION}

The correlation between the ${ }^{14} \mathrm{C}$ dates and the archaeological evidence leads to a refined chronology of the site. The Bayesian model shows that the oldest part of the bathhouse, heated by the furnace A36 (LTL4383A), was built between the second half of the 2 nd and the beginning of the 3rd century $\mathrm{AD}(68.2 \%)$. This first nucleus was enlarged westward around the beginning of the 4th century AD when the furnace A52 was built (LTL4381A). This furnace was in use at least until the end of the 4 th century as proved by the date LTL4382A.

In the 4th century $\mathrm{AD}$, the villa was also furnished with two granaries $\mathrm{A} 7$ and $\mathrm{A} 8$; the dates coming from A7 (phase 1) (LTL1713A and 1712A) date the construction of these storerooms to the middle of the 4th century AD. The latest evidence from the Late Roman period comes from the furnace A48 that was dated to the end of the 5th century AD. 
In the decades following the end of the 5th century $\mathrm{AD}$, the villa was in ruin and an ephemeral settlement arose around it. The hearth (LTL4379A) of the hut A79, dated to the first half of the 6th century AD, marks the beginning of the EMA period. Soon after the newcomers settled, they started the spoliation of the Roman ruins, discarding refuse in the dump A66. The charred grain of wheat collected in the dump (LTL3274A) dates the discarded material to the first half of the 4th century $\mathrm{AD}$, but material from later periods (second half of the 4th to 5th centuries $\mathrm{AD}$ ) was found as well.

Metal objects were likely the most wanted by the new settlers, since they could easily be reworked. Traces of metal slags, wood chunks, and branches in the dump A61 might represent the residues of activities aimed at melting and reusing the metals. The ${ }^{14} \mathrm{C}$ date of a branch of oak collected in A61 (LTL4385A) dates these activities around the first half of the 6th century AD.

During the following decades, the settlement apparently reached a certain degree of prosperity, since the storeroom A8 was cleaned and barley was stored in piles (LTL1985A, 1708A, 3272A). The last traces of these settlements date to the end of the 7th century AD, when the granary A7 was partially reused to stock wheat (LTL1710A, 1711A) (Figure 5).

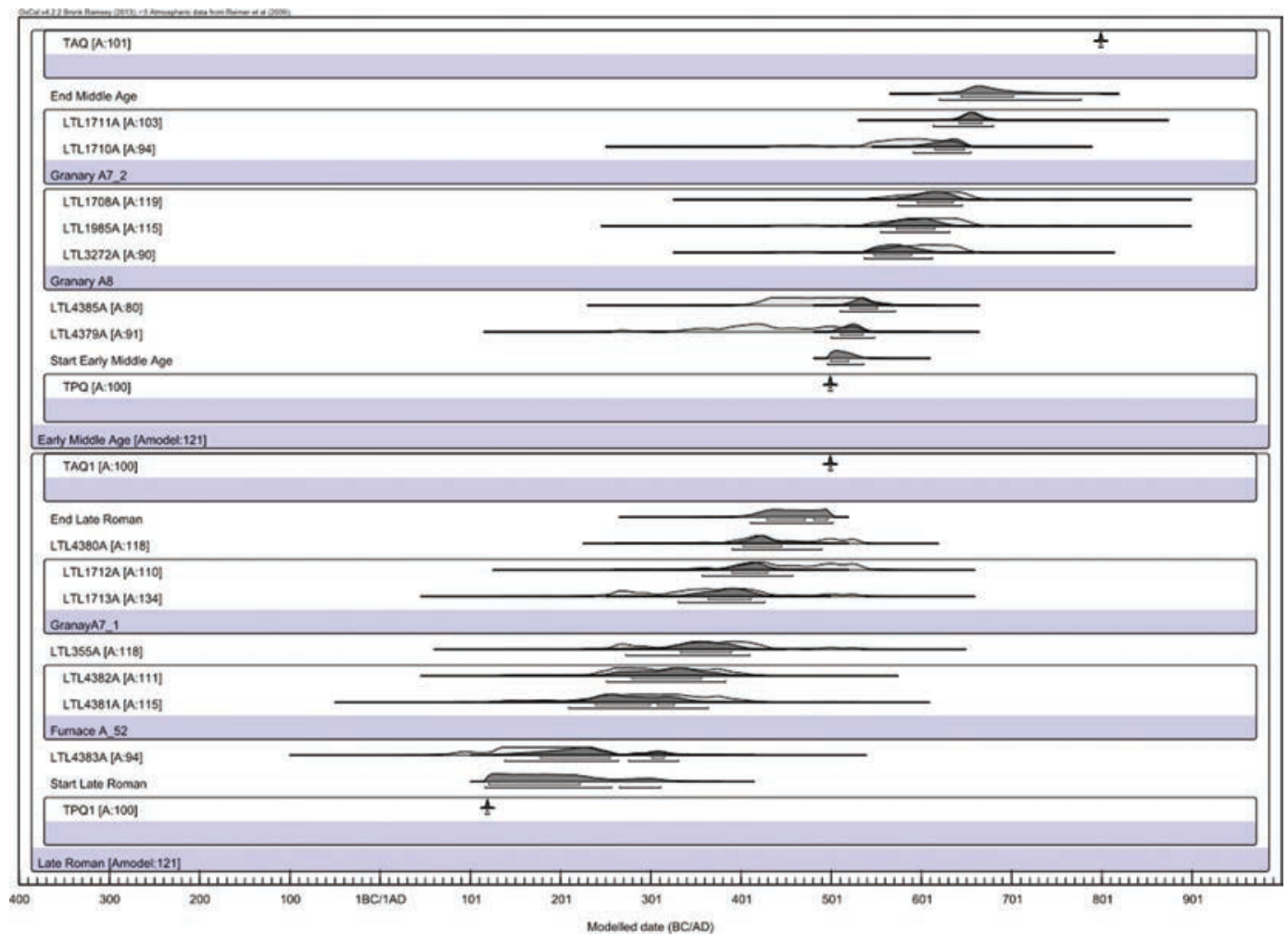

Figure 5 Bayesian model shows the sequence of ${ }^{14} \mathrm{C}$ dates

\section{CONCLUSION}

Dating the Late Roman/early Middle Ages site of Faragola with an exact chronology required an accurate selection of specimens. The contexts were studied in depth in order to understand the meaning of the plant remains and the possible sources of contamination. Wherever a combustion feature or a furnace was dated, wood was preferred to seeds, since wood was much likelier to be part 
of the original deposit; however, when the storerooms were dated, specimens were selected among the material that was meant to be stored.

Coupling ${ }^{14} \mathrm{C}$ dates and archaeological evidence was fundamental to refining the chronology of the site. The Roman villa developed between the 3rd century AD and the end of the 5th century AD. Then, the site was abandoned and later reoccupied in the 6th until the 7-8th centuries AD by new settlers that built structures on top of the Roman ruins. Thus far, the dates of Faragola represent the first successful attempt to determine the exact chronology of the transition from the Roman villa system to the Medieval village system in Apulia.

\section{ACKNOWLEDGMENTS}

The present work was funded by the DISCUM, University of Foggia, and is part of the research Dr Caracuta carried out during her PhD. Special thanks to Dr De Venuto, Goffredo, Buglione, and Sibiliano for their support during the fieldwork and the care taken while selecting the samples. The authors want to thank Prof Calcagnile and Drs Quarta and D'Elia from the CEDAD Laboratory, University of Salento, for measuring the ${ }^{14} \mathrm{C}$ age of the samples.

\section{REFERENCES}

Arthur P, Patterson H. 1994. Ceramics and early Medieval central and southern Italy: "a potted history." In: Francovich R, Noyé G, editors. La storia dell'Alto Medioevo italiano (VI-X secolo) alla luce dell'archeologia, Convegno internazionale (Siena, 2-6 settembre 1992). Firenze: All'Insegna del Giglio. p 409-41.

Arthur P, Patterson H. 1998. Local pottery in the southern Apulia in the 6th and 7th centuries AD. In: Saguì L, editors. Ceramica in Italia: VI-VII secolo, Atti in onore di J.W. Hayes. Firenze: All'Insegna del Giglio. p 511-30.

Bronk Ramsey C, Lee S. 2013. Recent and planned developments of the program OxCal. Radiocarbon 55(2):720-30.

Calcagnile L, Quarta G, D’Elia M. 2005. High resolution accelerator-based mass spectrometry: precision, accuracy and background. Applied Radiation and Isotopes 62(4):623-9.

Caracuta V, Fiorentino G. 2009. L'analisi archeobotanica nell'insediamento di Faragola (FG): il paesaggio vegetale tra spinte antropiche e caratteristiche ambientali, tra tardoantico e altomedioevo. In: Atti del $V$ Congresso Nazionale di Archeologia Medievale (Foggia-Manfredonia, 30 settembre-3 ottobre 2009). Firenze: All'insegna del Giglio. p 717-26.

Caracuta V, Fiorentino G. 2012. Wood for fuel in Roman hypocaust baths: new data from the Late-Roman villa of Faragola (S-E Italy). Saguntvm Extra 13:199-208.

Caracuta V, Fiorentino G, Turchiano M, Volpe G. 2012. Processi di formazione di due discariche altomedievali nel sito di Faragola. Il contributo dell' analisi archeobotanica. Post-Classical Archaeology 2:22546.

D’Elia M, Calcagnile L, Quarta G, Rizzo A, Sanapo C, Laudisa M, Toma U, Rizzo A. 2004. Sample preparation and blank values at the AMS radiocar- bon facility of the University of Lecce. Nuclear Instruments and Methods in Physics Research B 223-224:278-83.

Fiorentino G, Caracuta V, Volpe G, Turchiano M, Quarta G, D'Elia M, Calcagnile L. 2009. The First millennium AD climate fluctuations in the Tavoliere Plain (Apulia -Italy): new data from the ${ }^{14} \mathrm{C}$ AMS-dated plant remains from the archaeological site of Faragola. Nuclear Instruments and Methods in Physics Research B 268(7-8):1084-7.

Francovich R, Hodges R. 2003. Villa to Village. The transformation of the Roman countryside in Italy, $c$. 400-1000. London: Duckworth.

Goffredo R, Maruotti M. 2012. Il lavoro per il lavoro: fabbri, officine e cultura materiale nell'insediamento altomedievale di Faragola (Ascoli Satriano, FG). In: Redi F, Forgione A, editors. Atti del VI Congresso Nazionale di Archeologia Medievale (L'Aquila 1215 settembre 2012). Firenze: All'Insegna del Giglio. p 656-61.

La Salvia V. 2007. Iron Making during the Migration Period. The Case of Lombard. BAR International Series 1715. Oxford: Archaeopress.

Lewit T. 2003. 'Vaninshing villas': What happened to the élite rural habitations in the West in the 5th-6th c? Journal of Roman Archaeology 16:260-74.

Quarta G, D'Elia M, Valzano D, Calcagnile L. 2005. New bomb pulse radiocarbon records from annual tree rings in the Northern Hemisphere temperate region. Radiocarbon 47(1):27-30.

Reimer PJ, Baillie MGL, Bard E, Bayliss A, Beck JW, Blackwell PG, Bronk Ramsey C, Buck CE, Burr GS, Edwards RL, Friedrich M, Grootes PM, Guilderson TP, Hajdas I, Heaton TJ, Hogg AG, Hughen KA, Kaiser KF, Kromer B, McCormac FG, Manning SW, Reimer RW, Richards DA, Southon JR, Talamo S, Turney CSM, van der Plicht J, Weyhenmeyer CE. 2009. IntCal09 and Marine09 radiocarbon age cali- 
bration curves, 0-50,000 years cal BP. Radiocarbon 51(4):1111-50.

Scrima G, Turchiano M. 2012. Le ceramiche dei magazzini dell'abitato altomedievale di Faragola (Ascoli Satriano, FG). Tipologie, funzioni e significato sociale. In: Redi F, Forgione A, editors. Atti del VI Congresso Nazionale di Archeologia Medievale (L'Aquila 12-15 settembre 2012). Firenze: All'Insegna del Giglio. p 601-6.

Volpe G, Turchiano M, editors. 2009. Faragola 1. Un insediamento rurale nella valle del Carapelle. Studi e ricerche. Bari: Edipuglia.

Volpe G, Turchiano M. 2010. The last enclave. Rural settlement in the 5th century AD in Southern Italy: the case of Apulia. In: Delogu P, Gasparri S, editors Le trasformazioni del $V$ secolo. L'Italia, $i$ barbari $e$ l'Occidente romano. Turnhout: Brepols.
Volpe G, Turchiano M. 2012. La villa tardoantica e l'abitato altomedievale di Faragola (Ascoli Satriano). Römische Mitteilungen 118:455-91.

Volpe G, De Venuto G, Goffredo R, Turchiano M. 2009. L'abitato altomedievale di Faragola (Ascoli Satriano). In: Volpe G, Favia P, editors. Atti del V Congresso Nazionale di Archeologia Medievale (Foggia-Manfredonia, 30 settembre-3 ottobre 2009). Firenze: All'Insegna del Giglio. p 284-90.

Volpe G, Turchiano M, De Venuto G, Goffredo R. 2012. L'insediamento altomedievale di Faragola. Dinamiche insediative, assetti economici e cultura materiale tra VII e IX secolo. In: Ebanista C, Rotili $\mathrm{M}$, editors. La trasformazione del mondo romano $e$ le grandi migrazioni. Nuovi popoli dall'Europa settentrionale e centro-orientale alle coste del Mediterraneo. Cimitile: Tavolario Edizioni. p 239-63. 